Kastamonu Education Journal, 2021, Vol. 29, No:1, 1-12

doi: 10.24106/kefdergi.3874

| Research Article / Araştırma Makalesi |

Transition from College to Work Life: Career Adaptability and Career Optimism

\title{
Üniversiteden İş Hayatına Geçiş: Kariyer Uyumu ve İyimserliği
}

\section{Cennet Erdoğmuş Zorver ${ }^{1}$, Fidan Korkut Owen ${ }^{2}$}

Keywords

1.Career adaptability

and career optimism

2.Senior

undergraduates

3.College to work

transition

Anahtar Kelimeler

1.Kariyer uyumu ve iyimserliği

2.Son sınıf üniversite

öğrencisi

3.Okuldan iş hayatına

geçiş

\section{Received/Başvuru}

Tarihi

26.07.2019

Accepted / Kabul Tarihi 05.10 .2020

\section{Abstract}

Purpose: In this study whether career adaptability and career optimism of senior year undergraduate students change according to their gender, faculty, form of their faculty/ department choice, their plans upon what they are going to do after graduation, their thoughts about finding a job and about the fact that the job which they have found is related to the field they were graduated from was investigated.

Design/Methodology/Approach: For this purpose 323 final year undergraduate students who studied at different faculties in a state university in Ankara are included in this study. Career Adaptability and Optimism Scale (CAOS) and Personal Information Form were used. Data was analyzed with t test and one-way analysis of variance.

Findings: According to the findings of the research; CAOS points of the students, who studied at faculties which offers easy job finding opportunities or difficult job finding opportunities, who come the department with different reasons, whose thoughts about finding a job after graduation and about the fact that the job which they have found is related to the field they were graduated from are different. On the other hand there is no meaningful difference between gender variable and between the students whose plans upon what they are going to do after graduation are different in terms of CAOS.

Highlights: Findings were discussed in the view of literature and some recommendations were put forward in terms of career counseling.

Öz

Çalışmanın amacı: Bu araştırmada üniversite son sınıf öğrencilerinin cinsiyetleri, fakülteleri, okudukları fakülteyi/ bölümü seçme biçimleri, mezuniyet sonrası ne yapmayı planladıkları, iş bulma konusundaki düşünceleri, bulunacak işin mezun olunan alanla ilgili olmasına ilişkin düşüncelerine göre kariyer uyumu ve iyimserliklerinin değişip değişmediği araştırılmıştır.

Materyal ve Yöntem: Bu amaçla Ankara'daki bir devlet üniversitesindeki farklı fakültelere devam eden 323 son sınıf öğrencisine ulaşılmıştır. Ölçme aracı olarak Kariyer Uyumu ve İyimserliği Ölçeği (KUiÖ) ve Kişisel Bilgi Formu kullanılmıştır. Veriler t testi ve tek yönlü varyans analizi ile analiz edilmiştir.

Bulgular: Araştırma bulgularına göre, kolay ve zor iş bulunan fakültelerde okuyan, bölüme farklı gerekçelerle gelen, mezun olduktan sonra iş bulmayla ilgili düşünceleri ve bulacakları işin alanlarıyla ilgili olmasına ilişkin düşünceleri farklı olan öğrencilerin KUiö’den aldıkları puanlar farklılaşmaktadır. Öte yandan cinsiyetler arasında ve mezuniyet sonrası yapmayı planladıkları farklı olan öğrenciler arasında KUiö açısından anlamlı fark bulunamamıştır.

Önemli Vurgular: Bulgular alanyazın ışığında tartışılmış ve kariyer psikolojik danışmanlığı açısından bazı öneriler sunulmuştur.

\footnotetext{
${ }^{1}$ Corresponding Author, Etlik Public Education Center, Ministry of Education, Ankara, TÜRKIYE; https://orcid.org/0000-0002-6957-6709

2 Bahçeşehir University, Faculty of Educational Sciences, Psychological Counseling and Guidance Department, Beşiktaş, isTANBUL; https://orcid.org/0000-00030144-1521
} 


\section{INTRODUCTION}

Niles and Harris- Bowly (2013) explained the definition of career as a life-style concept instead of limiting it only with job/working concept. According to the authors, career is the total of roles which the individual plays during his/her whole life. Career development, according to Herr, Cramer and Niles (2004), is a broader concept involving individual's forming a career pattern, his/her decision taking style, integrating his/her life roles, expressing his/her values and self- concepts) upon his/her life role. In fact many years ago Super and Hall (1978) described career concept as a series of positions in which an individual comes through during his/her whole life; and they indicated that a career of an individual is a series of life stages in which the individual tries to cope with different developmental duties he/she encounters during his/her school and work life.

Super (1980) says that during their whole life individuals pass five developmental stages which have sub-levels as physical and physiological growth, research, taking a position, continuing the job and quitting the job about their career. According to him, research period which the individuals live between the ages 15-24 has three sub-levels as trial (age 15-17), transition (age 18-21) and testing (age 22-24). Super (1980) mentions that apart from the transition process in the research period, individuals experience career transitions when they pass from one career development process to an-other. According to this, career transition may be defined as successive career situations during career changes. These changes may occur as change of duty in the same job or workplace, change of position about the job being offered by the same or different workplace or employer and change of profession occurring in the same or different field (Hep-pner, 1998). While Scholessberg, Waters and Goodman (1995) explain adult career transitions with 4S (this is men-tioned as 4S as it stands for the first letters of words: situation, self, support, strategies in English) model, Bridges and Mitchell (1980) explain career transition by talking about three stages as finalizing a situation, entering a neutral field where explorations are done and new beginnings.

Another concept which is important in career transitions is the concept of transition from school to work. When litera-ture is investigated, it is seen that many theoreticians (Heckhausen, 2002; Herr, 1999; Lent, Hackett and Brown, 1999; Perren, Keller, Passardi and Scholz, 2010; Savickas, 2005; Super, 1980) express career transition process continuing from the graduation from high school or university to getting into a job as a process of transition from school to work and that they investigate the career transition processes from social, cognitive and developmental aspects. Savickas (1999) presented his works upon transition from school to work by associating the self-awareness of the individual, his/her knowledge about professions and importance of career planning with growth. He explained the developmental competencies and abilities in the transition process from school to work in five domains as self knowledge, professional knowledge, decision taking, planning and problem solving. Competencies in these domains support the individual's readiness, professional coping skills and his/her adaptability to transition process in a short time. In this transition pro-cess young people try to accommodate themselves to the new social roles and responsibility areas they obtained in society. Young peoples' adaptation to these processes and new situations are explained with the concept of career adaptability.

Career adaptability concept was built on Super's (1980) career maturity concept. Savickas (1997) explains individ-ual's ability to cope with changes in expected or unexpected situations with which the individual encounters during ca-reer transition process and to adapt himself/herself to new roles with career adaptability concept. Raskin (1998) ex-presses that the career adaptability concept shows broader, richer and more developmental structure than the career maturity concept. Factors such as selfawareness, professional awareness, social support, control, work/life balance and the self- confidence are important for the individual's coming over this adaptation process. On the other hand, the relation between optimism tendency which the individuals who are in above mentioned situation have while coping with new situ-ations and their adaptability process is remarkable. Savickas (2005) argues that career adaptability has four dimen-sions as concern, control, curiosity, confidence. According to him, individuals whose career adaptability is good may be conceptualized as individuals who concern and think about their professional future (first dimension), who gradually get their professional future under control (control), who are curious about exploring themselves and other possibilities (curiosity) and who have confidence in realizing their expectations. Another concept upon this subject is career opti-mism. Scheier, Carver and Bridges (1994) defines optimism as individuals' generally being in a positive expectation about obtaining positive results in the future against his/her behaviours. According to Scheier and Carver (1987) career optimism is that individuals have a positive perspective even though their expectations upon their career plans are hard to come true. There are studies in literature about career and optimism which are done with different groups who are in the career transition process (Nurmi, Salmela-Aro and Koivisto, 2002; Patton, Creed and Bartrum 2004; Schulenberg, Bry-ant and O'malley, 2004). In this study it was found out that there is a positive relation between career optimism and making plans upon career future, finding a job and continuing it, graduation successes and self-competence levels.

When the relation between career adaptability and career optimism is examined, it is seen that these two concepts are in similar relations with similar variables according to the results of researches made in literature (Balın, 2008; Pat-ton, Bartrum and Creed, 2004; Roberts, 2008; Schulenberg, Bryant and O'malley, 2004). In the researches made, a relation between career adaptability, optimism and hope (Büyükgöze-Kavas, 2014); between career adaptability, op-timism, being goal oriented and having proactive personality (Tolentino, Garcia, Lu, Restubog, Bordia ve Plewa, 2014) was determined. Also, it can be said that 
career adaptability and career optimism which have meaningful relations with career competence expectation (Prideaux and Creed, 2001), career result expectations (Rottinghaus, Bulelow, Matvia and Schneider, 2012), career decision taking obstacles (Hirschi and Valero, 2015) are interaction with each other. It is thought that career adaptability and optimism tendencies are related to each other in terms of focusing the positive as-pects of individuals' situations in order to optimize a given relationship situation. Except this a positive relation between career adaptability and control emotion (Duffy, 2010), being goal oriented and flexibility in adapting the change of goal was found (Tolentino, Raymund, Garcia, Restubog, Prashant and Tang, 2013).

One of the reasons why transition from university to working life is important is that finding a job after graduation is difficult. When unemployment rates among university graduates in other countries of the world are considered, when evaluated with developed and developing countries rates in Turkey are higher than other countries. By 2011, unem-ployment rate of university graduates in Germany was 3,1\%; in the USA the rate was 4,9\%; in England it was 4,1\%; in Bulgaria it was 4,5\%; in India it was 3,4\%; in Indonesia it was 1,1\% and in Turkey it was 9,8\% (ILO, 2012). According to another report, the rate of 15-24 age population within the total population is the highest in Turkey among EU-28 coun-tries. Young unemployed population among the total unemployed population was 20,74\% according to the 2014 EU-28 average. In other words $21 \%$ of each 100 unemployed people are young in EU-28 countries. When the rate of young unemployed people to the total young population is examined, in 2014 EU28 average was 9,1\%; that is nearly 9 of each 100 young people between the ages of $15-24$ is unemployed in EU-28 countries. When each of the indicators are investigated for Turkey, the youth unemployment rate was $17,8 \%$ in 2014 ; that is it is lower than EU-28 average (Yazar- Aslan, 2015). In Turkey unemployment rate increases depending on education level (Akgeyik, 2012; Kayahan Kara-kul, 2012). In other words especially young people of 20-24 ages who are educated labour force seem more disadvan-taged while finding a job. In the present case it is not surprising that university students are concerned about finding a job after graduation. According to Erdoğmuş (2001), in Turkey the most significant concern of the university students is to get a suitable job after graduation. The number of students graduating from universities (supply) is more than the demand in the market; so this concern increases more. Within this frame Dursun and Aytaç (2009) conducted a study with final year undergraduate students. In this study they found that the students who are not hopeful for finding a job after graduation have higher levels of continuous and situational concern and unhappiness than students who are hopeful about finding a job. In such a case students are obliged to find a job which they can work instead of working in a job which is suitable to their knowledge, skills, interests and values. Because, finding a job is a really hard process for most of the university graduates. According to Household Labour Force Researches in Turkey unemployment rate was 10,5\% in September 2014 period (Turkish Statistical Institute, 2014), it was 10,4\% in September 2015, it was 9,3\% in April 2016 (TSI, 2016a). According to labour force statistics, in 2014 unemployment rate of 1524 years young peo-ple was $17,9 \%$ however this rate has increased to $18,5 \%$ in 2015 . It was observed that in 2014 unemployment rate of higher education graduate people of the aforementioned year group was $28,3 \%$ however this rate has increased to $29,5 \%$ in 2015 (TSI, 2016b).

In the study conducted by Kayahan Karakul (2012) in line with TSI data; although there is change in some years, generally there is a tendency against women is seen in the rate of unemployed women and men who were graduated from university between the years 1989-2010. For instance, in 2004 the rate of unemployed women who are university graduates and women was (41.5; $37.7)$; in 2007 it was $(30.1 ; 26.3)$ and in 2010 it was $(36,7 ; 27,5)$. It was observed that in 2014 men's unemployment rate from 1524 years young people was $16,6 \%$ and this rate decreased to $16,5 \%$ in 2015 ; unemployment rate of women was 20,4 in 2014 ; however this rate increased to $22,2 \%$ in 2015 . Again within the same group the rate of unemployed men who are higher education graduates was $23,2 \%$ in year 2014; however this rate decreased to $21,5 \%$ in year 2015; and while the unemployment rate of women was 33,1\% in year 2014; it increased to 35,9\% in year 2015 (TSI, 2016b). Thus, it can be said that women are more disadvantaged in this subject. According TSI (2014) reports when unemployment rates are examined based on professions, the first three professions whose unemployment rates are the highest are journalism and informatics with the rate of $29,1 \%$, computer with the rate of $16,6 \%$, art with the rate of $16,3 \%$, life sciences with the rate of $15,1 \%$; and the professions whose unemployment rates are the lowest are security services with the rate of $2,5 \%$, health services with the rate of $3,2 \%$, veterinary medicine with the rate of $7,3 \%$ and teacher education and educational sciences with the rate of $7,4 \%$.

The gender of the individual involved in this study, whether he/she has chosen his/her faculty/ department willingly or unwillingly, what are his/her plans after graduation, his/her opinions upon finding a job after graduation and his/her thoughts about the situation that the job shall be related to his/her education field are among the variables which are related to career adaptability and career optimism. Researches about this subject are summarized as the following. When considered in terms of gender, Luzzo (1995), found out that the difference was in favour of women between the genders with regard to career maturity in the study he carried out with university students. As a result of the studies it was determined that women have higher career adaptability (Coetzee and Harry, 2014, Ferreira, 2012). In the study conducted by Sarıkaya and Khorshid (2009) with the students beginning to university instead of final year students, the reasons why these students prefer these professions were investigated according to the fact that if they chose the departments willingly or unwillingly. $45.9 \%$ of the students who chose their departments/ professions willingly expressed that they have positive opinions upon the profession and $25.8 \%$ of them expressed that they chose this department as they prioritize the advantages of the profession. Only $12.1 \%$ of them expressed that they chose the profession/ department upon the recommendations of others. On the other hand, $41.7 \%$ of the students who chose their 
departments/ professions unwillingly expressed that they chose the profession as they felt helplessness and $22.6 \%$ of them expressed that they chose the profession upon the recommendations of others. In a study which was conducted in line with hopelessness which is not directly related to career adaptability and optimism; but, is indirectly related to them; it was determined that the hopelessness of the students who chose their department willingly is lower (Üstün, Dedekoç, Kavalalı, Öztürk, Sapcı and Can, 2014). It was found in a similar study that the students who chose their department/school unwillingly have higher levels of concern (Deveci, Çalmaz and Açık, 2012). When findings are viewed, it can be thought that there is a difference between career development of people who chose their department willingly and of people who did not choose their department willingly. This gives rise to thought that how students choose their faculty/ department may affect their career adaptability and career optimism.

The concept of career adaptability and career optimism also includes making a career plan. For instance when Lip-tak (2001) talks about career maturity, he mentions about individual's readiness and willing to make a career plan. Also, within career maturity concept Seligman (1994) dwells on knowing how to make a plan and on making a plan by mentioning that her attitudes about career is positive. In a research carried out by Arslan (2002) students are asked "What is your professional ideal after graduating from university?". It was seen that with regard to professional ideals their first priority was establishing their own business $(45,6 \%)$, their second priority was working in private sector $(25,8 \%)$, their third priority was being academician $(8 \%)$ and their fourth priority was continuing their father's profession (7,6\%). Study results bring to mind that career adaptability and career optimism of the students can be changed according to the plans after graduation.

The number of university education fields is increasing; however, opportunities of getting a job are decreasing; thus encountering young people who cannot find a job for a few years after graduation is ordinary (Dursun and Aytaç, 2009). There are some studies upon this subject, in other words upon opinions of young people, who are in the process of finishing university and passing to working life, about finding a job after graduation. In the first of them Gizir (2005) found in the research made with final year undergraduate students that young people are primarily concerned about not finding a job. In another research made by Mütevellioğlu, Zanbak and Mert (2010) with final year undergraduate students, it was found that only less than one third of young people hope to find a job corresponding their expectations without having difficulty after graduation and that nearly half of them do not share this opinion. Also Dereli and Kabataş (2009) determined that generally most of the students do not share the opinion that they can find a job corre-sponding their expectations without having difficulty after graduation. In another study made with regard to process of hoping to find a job Üstün, Dedekoç, Kavalalı, Öztürk, Sapcı and Can (2014), it was found that total hopelessness point of the students expressing that duration of finding a job shall be less than 12-23 months is significantly lower than total hopelessness point of students thinking that duration of finding a job shall be more than $12-23$ months. Ac-cording to another result obtained by Yazar- Aslan (2015), while $40 \%$ of the participants think that they can find a job which is convenient to their education within three years, $37 \%$ of the participants think that they can find the afore-mentioned kind of job within a year. Also, $15 \%$ of the participants think they will not be able to find a job which is convenient to their education. These studies show the expectation of university graduates in Turkey about finding a job. Another subject is upon the fact whether the job which shall be found after graduation is related to the graduation field. Mütevellioğlu, Zanbak and Mert (2010) carried out a study upon this subject and nearly two third of the final year undergraduate students (68 percent) expressed that they want to work on the branch they have education; and the rest one third of the students gave either negative answer and/or expressed their uncertainty. In the research upon young people's transition to the labour force market, in TSI (2009) report it was determined that $2 \%$ of young people who worked in a job for more than three months after they completed their higher education worked in jobs that do not require any qualifications.

Summarized findings can be considered as indicators that young people who are in the process of transition from school to work need support within the frame of career physiological counselling. On the other hand, when literature is examined in Turkey there are limited numbers of studies conducted with individuals who are in the process of transition from school to work. The aim of this research is to search whether career adaptability and career optimism of final year undergraduate students change according to their gender, faculty, form of their faculty/ department choice, their plans upon what they are going to do after graduation, their thoughts about finding a job and their thoughts about the fact that the job which they have found is related to the field they were graduated from.

\section{METHOD}

Scanning method was used in this research. Research group, data collecting tools, collecting the data and analysing the data are mentioned below.

\section{Research Group}

Data was collected from faculties of a state university located in Ankara at the end of 2013-2014 educational year's spring term for this research. When the research group was chosen, a convenience sampling method was used. Based on TSI statistics (2014) total 323 final year undergraduate students are accessed; and these students are from Veteri-nary School ( $N=53)$ and from Education Faculty $(\mathrm{N}=111)$ graduates of which can find a job most easily; and from Faculty of Agriculture ( $\mathrm{N}=76$ ) and Communication Faculty ( $\mathrm{N}=83$ ) graduates of which can find a job difficulty. 16 students did not answer the question about how

| Kastamonu Education Journal, 2021, Vol. 29, No. 1 | 
they chose their department, 53 students did not answer the question about what they are going to do after graduation, 95 of the students did not answer the question about the job which they shall find will be convenient to their profession and 51 of the students did not answer the question about the opin-ions upon finding a job.

\section{Data Collecting Tools}

\section{Career Adaptability and Optimism Scale (CAOS)}

CAOS was developed by Erdoğmuş-Zorver and Korkut Owen (2014) in order to measure the career adaptability and career optimism of the individuals who are up to pass working life from university life. While developing the scale with-in the frame of Super's (1980) developmental and life long career development theory, authors benefited from Savickas' (1997) career adaptability concept, Scheier and Carver's (1987) career optimism concept and from Career Future Inventory (CFI) developed by Rottinghaus (2005). Exploratory factor analysis was done to data obtained over 77 items form of scale in structural validity works. Conformity of the data for factor analysis was investigated with Kaiser-Meyer-Olkin (KMO) coefficient and Bartlett Sphericity test. $\mathrm{KMO}$ value was meaningful in level .95 and Bartlett Sphericity test was meaningful in level .00; thus data was proved to be suitable for analysis. Article factor distribution and eigenvalue graphics of CAOS indicate that the scale has a one dimensional structure. Total variance explained in the last version including 18 articles which obtained as a result of analyses was found as $43,79 \%$ (Erdoğmuş-Zorver and Korkut Owen, 2014).

As a result of DFA, RMSEA and SRMR values were 0,06 and 0,04 in relation with the single factor scale com-prising 18 articles; and this was interpreted by the researchers as the model's compatibility is acceptable. For CAOS, GFI was found as 0.90 and CFI was found as 0.93. Besides this RMSEA was calculated as 0.06 and SRMR was calculated as .04. Obtained values were interpreted as an important proof that the model is a good one. According to the findings obtained within criterion validity, a meaningful relation was found between Professional Result Expectation Scale (Işık, 2010) and CAOS as $r=0.60$ ( $p<0.01)$. Internal consistency coefficient was found as 0.93 and test- retest reliability was found as 0.85 in reliability studies. From 18 to 90 points can be taken from the scale and the higher the point taken is, the more the level of career adaptability and career optimism are (ErdoğmuşZorver and Korkut Owen, 2014).

\section{Personal Information Form}

The form which was developed by the researchers for measuring students' demographic features and some features upon career involves six questions in total. The first two of these questions are about the gender and name of the facul-ty which the students attend. One of the questions upon the career is about the careers of the students, in other words about how they decided to choose the faculty they study. Choices are as the following: (1) I chose it according to my wish, interest, ability, (2) the point I got from the exam is only enough for this faculty, (3) department is popular and I thought finding a job is easy and (4) I chose it with the recommendations of the people around me (mother and father, teacher, physiological counsellor, etc.). Other questions are about what are they planning to do after graduation (imme-diately finding a job in public or private sector, doing his/her own/ family job, doing master degree/ abroad experience or other), their thoughts about finding a job ( $\mathrm{c}$ can find a job as soon as possible and I may not find a job in a short time) and their thoughts about the situation if the job they shall find will be related to the field they are going to gradu-ate from (the job I will find must be related to the field I am going to graduate from and it is not necessary that the job I will find must be related to the field I am going to graduate from).

\section{Collecting and Analysing The Data}

At the end of 2013-2014 educational year's spring term, final year undergraduate students from four different fac-ulties as agriculture, veterinary, education and communication, of a state university in Ankara were accessed via their departments' lecturers. From these students the ones who are willing to participate in the research filled personal infor-mation form and scale which were prepared by the researchers. Applications were completed in four weeks. T test and one- way analysis of variance were used in the analysis of the data. In the one- way analysis of variance, as the vari-ances were not homogenous in accordance with Levene test, homogeneity of the variances were arranged by using Welch and Brown- Forsythe tests (Field, 2009, s.279, Gastwirth, Gel and Miao, 2009, s.3; Roth, 1983). These two tests provide the confirmation of null hypothesis even when the ingroup variance is heterogeneous and a comment of $p$ value is made as it is made in a variance analysis table (XLSATAT, 2015). If the results are meaningful, Games- Howell test was used as post hoc (Field, 2016, s.7). Analyses were done via SPSS 13 program.

\section{FINDINGS}

In this section firstly descriptive statistics about variables are given then findings are given according to the se-quence in the research problem. Descriptive statistics of CAOS scores according to different variables are presented in Table 1.

\section{Tablo 1. Descriptive Statistics}




\begin{tabular}{|c|c|c|c|c|}
\hline Variables & & $\mathrm{n}$ & Average & Standard Deviation \\
\hline \multirow{2}{*}{ Faculty } & $\begin{array}{l}\text { Faculties from which } \\
\text { finding a job is difficult }\end{array}$ & 159 & 65.62 & 11.18 \\
\hline & $\begin{array}{l}\text { Faculties from which } \\
\text { finding a job is easy }\end{array}$ & 164 & 68.62 & 12.53 \\
\hline \multirow{2}{*}{ Gender } & Woman & 156 & 66.96 & 11.58 \\
\hline & Man & 167 & 67.31 & 12.34 \\
\hline \multirow{4}{*}{$\begin{array}{l}\text { Form of choosing the } \\
\text { department }\end{array}$} & $\begin{array}{l}\text { My interest, ability, } \\
\text { gender }\end{array}$ & 156 & 70.37 & 9.8 \\
\hline & $\begin{array}{l}\text { My university exam } \\
\text { score }\end{array}$ & 56 & 62.53 & 13.54 \\
\hline & $\begin{array}{l}\text { Popular and finding a job } \\
\text { will be easy }\end{array}$ & 34 & 62.02 & 14.21 \\
\hline & $\begin{array}{l}\text { Mother- father, teacher, } \\
\text { physiological counselor }\end{array}$ & 61 & 65.50 & 11.17 \\
\hline \multirow{4}{*}{$\begin{array}{l}\text { Plans about what they are } \\
\text { going to do after } \\
\text { graduation }\end{array}$} & $\begin{array}{l}\text { Finding a job in public/ } \\
\text { private sector }\end{array}$ & 38 & 64.00 & 17.52 \\
\hline & His/her own/ family job & 125 & 65.92 & 11.21 \\
\hline & Abroad/ master degree & 76 & 68.98 & 9.48 \\
\hline & Other & 70 & 69.96 & 10.96 \\
\hline \multirow{2}{*}{$\begin{array}{l}\text { Opinions about finding a } \\
\text { job }\end{array}$} & $\begin{array}{c}\text { I can find a job as soon } \\
\text { as possible }\end{array}$ & 76 & 61.77 & 15.23 \\
\hline & $\begin{array}{l}\text { I may not find a job in a } \\
\text { short time }\end{array}$ & 106 & 69.96 & 9.97 \\
\hline \multirow{2}{*}{$\begin{array}{l}\text { Relation of the job to be } \\
\text { found with the field to be } \\
\text { graduated from }\end{array}$} & $\begin{array}{l}\text { It must be related to my } \\
\text { field }\end{array}$ & 77 & 60.96 & 12.84 \\
\hline & $\begin{array}{l}\text { It may not be related to } \\
\text { my field }\end{array}$ & 151 & 68.22 & 11.26 \\
\hline
\end{tabular}

According to the results of $t$ test which was made in order to determine whether the scores, which were taken from CAOS by final year undergraduate students whose faculties are different, are different or not; there was a mean-ingful difference among the faculties ( $t=2.27, p>0.02$ ). Thus, scores which were taken from CAOS by the students from faculties that were reported as easy job finding faculties and difficult job finding faculties by TSI were different from each other. When averages were examined, it was seen that students studying at faculties which they can find a job easily after graduation are advantageous.

According to the results of $t$ test which was made in order to determine whether the scores, which were taken from CAOS by final year undergraduate students whose genders are different, are different or not; there was not a meaningful difference among the genders $(t=.26, p<0.05)$. Thus, the scores, taken from CAOS by university students whose genders are different, were not different from each other.

According to the results of one-way variance analysis which was made in order to determine whether the scores, which were taken from CAOS by final year undergraduate students whose reasons for choosing this department/ fac-ulty are different, are different or not; there was a meaningful difference $(F(3,303)=9.98 ; p>0.0001)$. But, as it was found that variances were not homogenous as a result of Levene test, Welch and Brown-Forsyte tests (Field, 2009, s.279, Gastwirth, Gel and Miao, 2009, p.3; Roth, 1983) had to be made in order to correct this situation. In these tests again the difference among the groups were meaningful.

Tablo 2. Results of One-Way Variance Analysis applied to CAOS Scores of Students Whose Forms of Choosing the Faculty They Study are Different

\begin{tabular}{|c|c|c|c|c|c|}
\hline Source of the Variance & Sum of Squares & $\mathrm{sd}$ & Average of Squares & $\mathrm{F}$ & \\
\hline Intergroup & 3871.228 & 3 & 1290.409 & 9.98 & .0001 \\
\hline In-group & 39166.813 & 303 & 129.263 & & \\
\hline Total & 43038.09 & 306 & & & \\
\hline
\end{tabular}

The results of one-way variance analysis are given above in Table 2 and the results of Welch and Brown-Forsythe test are given below in Table 3. These tests show that there are meaningful differences among the groups.

Tablo 3. Results of Welch and Brown-Forsythe Test applied to CAOS Scores of Students Whose Forms of Choosing the Faculty They Study are Different. 


\begin{tabular}{|l|l|l|l|}
\hline & Statistics ${ }^{\text {a }}$ & Df 1 & Df 2 \\
\hline Welch & 8.980 & 3 & 95.285 \\
\hline Brown-Forstyhe & 8.115 & 3 & 145.103 \\
\hline
\end{tabular}

a $\mathrm{F}$ which distributed in an asymptotic way

This situation shows that there are meaningful differences among the students whose form of choosing the department they study is different. In order to understand which difference among which groups leads this difference Games- Howell (Field, 2016) test was applied; and it was found that there was a meaningful difference between the CAOS points of students who are the first group, that is who have come to the department due to their interests, abili-ties, gender and the CAOS points of other three groups.

In the present case there is meaningful difference between the ones who have come to the department due to personal reasons such as interest, ability, gender $(=70.37)$ and the ones who have come to department as the universi-ty exam score they got is only enough for the department $(=62.52)$ (Games-Howel= 7.84, p>0.001); the ones who think the department is popular and finding a job is easy $(=62.02)$ (Games-Howel $=8.34, p>0.01$ ) and the ones who have come to the department with the effect of their mother-father, teacher or physiological counsellor $(=65.50)$ (Games-Howel $=4.87, p>0.01)$. When averages are examined, it is seen that career adaptability and career optimism of the students who have come to the department due to personal reasons such as interest, ability and gender are higher.

According to the results of one-way variance analysis which was made in order to determine whether the ecores, which were taken from CAOS by final year undergraduate students whose wishes about what they are going to do after graduation are different, are different or not; there was a meaningful difference $(F(3,305)=2.86 ; p>0.03)$. But, as it was found that variances were not homogenous as a result of Levene test, Welch and Brown-Forsyte tests (Field, 2009, s.279, Gastwirth, Gel and Miao, 2009, s.3; Roth, 1983) had to be made in order to correct this situation. But, as it can be seen in Table 4, there is not a meaningful difference among the groups in these tests.

Tablo 4. Results of Welch and Brown-Forsythe Test applied to CAOS Scores of Students Whose Plans After Graduation are Different.

\begin{tabular}{|l|l|l|l|l|}
\hline \multicolumn{2}{l}{ Statistics $^{\mathrm{a}}$} & Df 1 & Df 2 & \multicolumn{1}{l|}{ p } \\
\hline Welch & 2.276 & 3 & 118.976 & .083 \\
\hline Brown-Forstyhe & 2.341 & 3 & 116.387 & .077 \\
\hline
\end{tabular}

a $\mathrm{F}$ which distributed in an asymptotic way

In this situation the points taken from CAOS by the students, whose wishes about what they are going to do af-ter graduation are different, are not different. In the present case it can be said that career adaptability and career opti-mism of the students do not change no matter what their graduation plans are.

According to the results of $t$ test which was made in order to determine whether the scores, which were taken from CAOS by undergraduate students whose thoughts about finding a job after graduation are different, are differ-ent or not; there was a meaningful difference among the groups ( $t=4.34, p>0.001)$. Thus the scores, taken from CAOS by the students who think they are going to find a job immediately after graduation and by the students who think they are not going to find a job in a short time after graduation, are different. When it is considered the thoughts about find-ing a job after graduation, the scores taken from CAOS by the students who thinks they are not going to find a job in a short time after graduation $(=69.96)$ is higher than the scores taken by the students who think they are going to find a job immediately after graduation $(=61.77)$. At present case it seems that career adaptability and career optimism of the students who think they are not going to find a job in a short time after graduation are better.

According to the results of $t$ test which was made in order to determine whether the points, which were taken from CAOS by undergraduate students whose wishes about finding a job which is related to their field are different, are different or not; there was a meaningful difference among two groups $(t=4.38, p>0.0001)$. When averages are exam-ined, CAOS point averages of the students who think the job they are going to find will not be necessarily related to the field they will be graduated from $(=68.22)$ are higher than the CAOS point averages of the students who want to find a job which is related to the field they will be graduated from $(=60.96)$. At present case it is seen that career adapta-bility and career optimism of the students, who think the job they are going to find will not be necessarily related to the field they will be graduated from, are better. 


\section{DISCUSSION}

In this research it was searched that whether the CAOS points of the final year undergraduate students change or not change according to some variables. Findings obtained are discussed below in the light of literature in accordance with the sequence of the variables.

When we look faculty variable, it is seen that career adaptability and career optimism of the students, who will be graduated from the faculties from which they can find a job easily, are higher than the students who will be gradu-ated from the faculties from which they can find a job difficulty. As it was determined in TSI (2014), finding a job is relatively easier after graduating from some fields. It is thought that expectations and belief of the students who are studying in these faculties upon finding a job are higher. Thus, it can be said that career adaptability of the people graduating from easy job finding faculties is higher and in this sense transition from university life to working life can relatively be easier for them.

When the findings are examined in terms of gender, it is seen that career adaptability and career optimism of the women and men students do not change. Researches show that with regard to gender there is a difference in favour of women in terms of career maturity (Coetzee and Harry, 2014; Ferreira, 2012; Luzzo, 2003). Also, in TSI (2016b) report it is reported that the unemployment rate for university graduate women is higher. So, it was thought that CAOSs' of women and men students could be different. Finding obtained shows that career adaptability and career optimism do not change according to gender.

How the individuals come to the faculty is important with regard to showing that they have chosen their career on their own or by the wishes of others or due to obligation. In this research it was found that CAOS points of the stu-dents whose form of coming to the faculty is different change. This shows that how the students have come to the faculties from which they can find a job easily or difficulty is related to career adaptability and career optimism. The situa-tion that points taken from CAOS by the students who have chosen easy job finding faculties due to their own qualifi-cations are high is expectable in accordance with the opinions of Savickas (2005). Thus it is seen that career adaptabil-ity and career optimism of the students who have chosen the faculty due to their own qualifications are higher than the ones who have chosen the faculty due to the point they took from university admission exam, as they see the depart-ment popular and they think finding a job will be easy or who have come with the recommendation of the others. This resembles the opinions of Savickas (2005) and research results of Sarıkaya and Khorshid (2009). Also, this finding is close to the findings that students who have chosen their departments unwillingly have higher concern (Deveci, Çalmaz and Açık, 2012) and hopelessness (Üstün, Dedekoç, Kavalalı, Öztürk, Sapcı and Can, 2014).

According to one-way variance analysis results points, taken from CAOS by the students whose wishes about what they are going to after graduating from easy job finding and difficult job finding faculties are different, are not different. When the points taken from CAOS by the students are examined according to their plans after graduation, there is no meaningful difference among the ones who plan to find a public or private sector, who plan to do their own job or family job, who plan to do master degree or to go abroad and who have different plans. This variable was dealt; because it was thought that career adaptability and career optimism could change according to the different career plans of the students. For instance, in a research carried out by Arslan (2002) it was determined that nearly half of final year undergraduate students answered the question upon what they were planning to do after graduation as they pre-ferred to establish their own business. In another study it was found out that a significant amount of university students were apt to do a master degree before beginning a professional life (Akoğlu-Kozak ve Dalkıranoğlu, 2013). In this study, even if there is no meaningful difference, the averages of the ones who plan to do a master degree and who have different plans are higher. This finding is close to the findings of Akoğlu-Kozak and Dalkıranoğlu'nun (2013)in one sense.

One of the findings of the research is that CAOS points of the students who have different opinions about finding a job after graduation change. CAOS points of the ones who think they shall find a job immediately are lower than the ones who think they shall not find a job in a short time. This finding is interesting because it shows that career adaptability and career optimism of the ones who think they shall not find a job in a short time are higher than the ones who think they shall find a job immediately. In the light of TSI $(2014,2016 \mathrm{~b})$ reports it can be said that in a way the students who think they shall not find a job in a short time search and evaluate both themselves and the conditions of the country objectively; and they have a better awareness. Eventually when the realities of the country, unemploy-ment rates and unemployment duration are taken into consideration, it is not surprising that the students who think they shall not find a job in a short time have higher points from CAOS. Studies done with final year undergraduate stu-dents show that most of the students do not hope to find a job immediately after the graduation (Dereli and Kabataş, 2009; Mütevellioğlu, Zanbak and Mert, 2010). Finding obtained in this research seems consistent with the findings of other researches.

One of the findings obtained from the research is that CAOS points of the students who have different opinions about the necessity that the job which they shall find after graduation must be related to their field change. According to this, CAOS point averages of the ones who think it is not necessary that the job which they shall find after gradua-tion must be related to their field are higher than the ones who want to find jobs related to their field. In a study done by Mütevellioğlu, Zanbak and Mert (2010) it

| Kastamonu Education Journal, 2021, Vol. 29, No. 1| 
was found that nearly two thirds of the students want to work on the branch they are educated in. On the other hand it was determined that career adaptability of the students who say they can work on a field other than the one they are educated in is higher. Career adaptability and career optimism concept including a series of structure (Griffin and Hesketh, 2005) involves flexibility, too (Herr and Cramer, 1992). Tolentino, Raymund, Garcia, Restubog, Prashant and Tang da (2013) found that there is a positive relation between career adaptability and adaptation to the change of goal and being flexible. Thus, we can think that the students who think they can work on the sectors other than the field they will graduate from are flexible. Also, Gündoğan (2005) expressed that young people who are in the transition process from school to work will either get a job which is suitable to the education they got and on which they can use the abilities they obtained from the education or not get a job for a long time or accept to work in underemployment with a low fee. It is reported in the recent studies that students are indecisive to plan their professional careers and that they consider the employment options in labour force market in different positions, not in the jobs upon which they are educated (Akoğlu-Kozak and Dalkıranoğlu, 2013; Beduwe and Giret, 2011; Laker and Laker, 2007). In a study realized in Turkey with the students who are just graduated from the university (Elhan, 2016) it was found that all of the participants look for a job except their fields; and that during this process they are stressed between the job which they want/ dream of and any job which they accept for not being unemployed anymore. By looking at the results of the research, another explanation can be that the ones, who think it is not necessary that the job they shall find will be related to their field, think that they can do jobs which are not related to their field in order not to be unemployed.

\section{RESULT AND RECOMMENDATIONS}

According to the finding of the research career adaptability and career optimism of the final year undergraduate students change according to their faculties, their reason of coming to the department, their opinions about finding a job after graduation and their opinions about the situation that the job they shall find is related to their field or not related to it. However, there is no meaningful difference between the women and men students; and between the ones whose plans after graduation are different with regard to career adaptability and career optimism.

Gündoğan (2005) expressed that one of the most important goals of contemporary societies is preparing the young people for the labour force market. It is expressed in different studies that it is necessary to help the youth in order to achieve this goal. For instance, Niles and Bowlbey (2013) indicated that students of higher education need assistance for participating in experiential career activities in order to make effective decisions. Elhan (2016) mentions that they emphasized the deficiency of a structure which shall support the university graduates while looking for a job, which shall provide opportunities for increasing their professional qualifications and where they can gather together in order to share their experiences/opinions/problems with their peers who are also looking for a job. In this process, more ac-tive working of career planning or developing centres which shall be active within the university body comes into prom-inence. Despite the fact that Özden (2015) determined that in most of the career centres within the university bodies the activities which are done most are publication and introduction, communication with the graduated students, searching the employment opportunities, career seminars, career guidance counselling and internship; there are no studies upon the fact that these centres are effective. Career physiological counsellors and other members of professions about ca-reer may need to better understand and analyse the necessities of students who are close to graduation with rapidly changing and globalizing business world dynamics. In this context they need to have knowledge and skills which may ease the transition from university to work. According to the findings when we consider the positive relation between willingly coming to department and career adaptability and career optimism, we must emphasize the importance of the career physiological counselling services provided to the students while they choose their university; and we must also express that the continuity of these services is necessary.

More studies need to be done on career adaptability and career optimism. Preparing programs which can ease the transition process for the students who are close to be graduated from university and making experimental works upon the effectiveness of above mentioned programs shall be meaningful. One of the limitedness of this study is that samples are taken from the faculties of a single university. Thus, it will be beneficial that similar studies upon career adaptability and career optimism include faculties of different universities; and that studies include variables such as risk taking, future expectation, career self-competence.

\section{Ethics Committee Approval Information}

This research was conducted in accordance with all ethical rules. There is no financial or moral conflict of interest between researchers. Research data were collected before 2019. Therefore, ethics committee approval was not required.

\section{REFERENCES}

Akgeyik, T. (2012). Üniversite mezunu gençler arasında vasıf formasyonu sorunu ve işsizlik olgusu, İstihdamda 3i Dergisi, Ekim-Kasım-Aralık 2012 dönemi, 7, 58-59. 
Akoğlu-Kozak, M. ve Dalkıranoğlu, T. (2013). Mezun öğrencilerin kariyer algılamaları: Anadolu Üniversitesi örneği, Anadolu Üniversitesi Sosyal Bilimler Dergisi, 13(1), 41-52.

Arslan, K. (2002). Üniversiteli gençlerde mesleki tercihler ve girişimcilik eğilimleri. Doğuş Üniversitesi Dergisi, 6, 1-11

Balın, E. (2008). The role of perceived career barriers and gender in predicting commitment to career choices of univer-sity students. A Thesis Submitted to The Graduate School of Social Sciences of Middle East Technical Univer-sity, Ankara.

Beduwe, C. ve Giret, J.F. (2011). Mismatch of vocational graduates: What penalty on French labour market? Journal of Vocational Behavior, 78 , 68-79

Bridges, W. ve Mitchell, S. (1980). Leading transition: A new model for change. Berlin, Eaton ve Associates Ltd., www.berlineaton.com.

Büyükgöze Kavas, A. (2014). Validation of the Career Adapt-Abilities Scale-Turkish Form and its relation to hope and optimism. Australian Journal of Career Development, 23, 125-132.

Coetzee, M., ve Harry, N. (2014). Emotional intelligence as a predictor of employees' career adaptability. Journal of Vocational Behavior, 84(1), 90-97.

Dereli, F. ve Kabataş, S. (2009), Sağlık Yüksekokulu son sınıf öğrencilerinin iş bulma endişeleri ve umutsuzluk düzeylerinin belirlenmesi, Yeni Tıp Dergisi, 26, s31-36.

Deveci, S.E., Çalmaz, A. ve Açık, Y. (2012). Doğu Anadolu'da yeni açılan bir üniversitenin öğrencilerinde kaygı düzeylerinin sağlık, sosyal ve demografik faktörlerle ilişkisi, Dicle Tıp Dergisi, 39 (2), 189-196.

Duffy, R.D. (2010). Sense of control and career adaptability among undergraduate students. Journal of Career Assessment, 18(4), 420-430. http://dx.doi.org/10.1177/1069072710374587

Dursun, S. ve Aytaç, S. (2009). Üniversite öğrencileri arasında işsizlik kaygısı. Uludağ Üniversitesi İktisadi ve Idari Bilimler Fakültesi Dergisi, 27(1), 71-84.

Elhan, U. (2016). Gençlik ve istihdam Odak Grup Araştırması, 2014 Yayın Tarihi. 2016

http://www.esassosyal.org/files/arastirmalar/EsasSosyal-Bilgi-Genclik-ve-Istihdam-Odak-Grup-Raporu.pdf

Erdoğmuş, N. (2001). Üniversitelerdeki kariyer merkezlerinin etkinlikleri hakkında bir araştırma. Kuram ve Uygulamada Eğitim Bilimleri, 1(1), 131142.

Erdoğmuş Zorver, C., \& Korkut Owen, F. (2014). Kariyer Uyumu ve İyimserliği Ölçeği'nin geliştirilmesi. International Journal of Human Sciences, 11(2), 314-331. doi: 10.14687/ijhs.v11i2.2911 328

Ferreira, N. (2012). Constructing a psychological career profile for staff retention. Unpublished doctoral dissertation. University of South Africa, Pretoria, South Africa.

Field, A. (2009). Discovering Statistics using SPSS (And sex and drugs and rock ' $n$ ' roll), 3rd ed., London: SAGE.

Field, A. (2016). One way independent ANOVA, http://www.statisticshell.com/docs/onewayanova.pdf

Gastwirth, J.L., Gel, Y.R. ve Miao, W. (2009). The impact of Levene's Test of equality of variances on statistical the-ory and practice. Statistical Science, 24(3), 343-360, DOI: 10.1214/09-STS301

Gizir, C.A. (2005), Orta Doğu Teknik Üniversitesi son sınıf öğrencilerinin problemleri üzerine bir çalışma, Mersin Üniversitesi Eğitim Fakültesi Dergisi, 1(2), 196-213.

Griffin, B. ve Hesketh, B. (2005). Are conscientious workers adaptable? Australian Journal of Management, 30, $245-260$. doi=10.1177/031289620503000204

Gündoğan, N. (2005). Okuldan çalışma hayatına geçiş: Örnek uygulamalar. İstanbul Üniversitesi Iktisat Fakültesi Mecmuası, 55(1), 105- 122

Herr, E. L. (1999). Theoretical perspectives on the school- to -work transition: Reactions and recommendations. The Career Development Quarterly, 47, 359-364.

Herr, E. L. ve Cramer, S. H. (1992). Career guidance and counselling through the lifespan. New York, NY: Haper Col-lins.

Herr, E. L. ve Crammer, S. H. (1996). Career guidance and counseling through the lifespan (5th Ed). New York: Har-perCollins Publishers.

Heppner, M. J. (1998). The Career transition inventory: Measuring internal resources in adulthood. Journal of Career Assessment, 6, $135-145$.

Hirschi, A. ve Valero, D. (2015). Career adaptability profiles and their relationship to adaptivity and adapting. Journal of Vocational Behavior, 88,220-229, doi:10.1016/j.jvb.2015.03.010

ILO (2012). Sustainable enterprises creating more and better jobs, International Labour Office, Geneva: Switzerland,http://www.ilo.org/wcmsp5/groups/public/---ed_emp/---emp_ent/documents/publication/wcms_175537.pdf

Kayahan Karakul, A. (2012). Türkiye'de üniversite mezunlarının işsizliğinin eleştirel bir çözümlemesi, Ankara Üniversitesi, Eğitim Bilimleri Enstitüsü, Yayınlanmamış doktora tezi.

Laker, D. R. ve Laker, R. (2007). The five-year resume: A career planning exercise. Journal of Management Education, 31(1), 128-142

Lent, R. W., Hackett G. ve Brown, S. D. (1999). A social cognitive view of school- to- work transition. The Career Development Quarterly, 47, 297311.

Liptak, J. J. (2001). Treatment planning in career counseling. Belmont, CA: Thomson Brooks/Cole.

Luzzo, D.A. (1995). Gender differences in college students' career maturity and perceived barriers in career development. Journal of Counseling and Development, 73(3):319-322. doi: 10.1002/j.1556-6676.1995.tb01756.x

Michelozzi, B.N., Surrell, L.J. ve Cobez, R.I. (2004). Coming alive from nine to five in a 24/7 world. New York: McGraw-Hill. 
Mütevellioğlu, N., Zanbak, M. ve Mert, M. (2010). İşsizlik, üniversiteli gençlik ve gelecek: Bir alan araştırmasının bulguları, C.Ü. iktisadi ve Idari Bilimler Dergisi, 11(1), 207-229.

Niles, S.G. ve Harris-Bowbly, J. (2013). Career development interventions in the 21st century, Fourth Edition, Pearson.

Nurmi, J. E., Salmela-Aro, K. ve Koivisto, P. (2002). Goal importance and related achievement beliefs and emotions during the transition from vocational school to work: Antecedents and consequences. Journal of Vocational Behavior, 60, $241-261$.

Özden, M.C. (2015). Üniversite yönetmelikleri çerçevesinde kariyer merkezlerinin amaç ve faaliyetleri, Karadeniz Sosyal Bilimler Dergisi, 7(12), 145-169.

Patton, W., Bartrum, D. A. ve Creed, P. A. (2004) Gender differences for optimism, self-esteem, expectations and goals in predicting career planning and exploration in adolescents. International Journal for Educational and Vocational Guidance, 4(3), 193-209.

Perren, S., Keller, R., Passardi, M. ve Scholz, U. (2010). Original communication well-being curves across transitions the development of a retrospective measure. Swiss Journal of Psychology, 69 (1), 15-29.

Prideaux, L. ve Creed, P. A. (2001). Career maturity, career decision-making self-efficacy and career indecision: A review of the accrued evidence. Australian Journal of Career Development, 10(3), 7-12.

Raskin, P. M. (1998). Career maturity: The construct's validity, vitality, and viability. The Career Development Quarterly, 47, 32-35.

Roberts, M. J. (2008). School to career transitions: career awareness and CTE students. A Dissertation Submitted to The Faculty of The Graduate School of The University of Minnesota.

Roth, A.J. (1983). Robust trend tests derived and simulated: analogs of the Welch and Brown-Forsythe Tests. Journal of the American Statistical Association, 78(384). 972-980.

Rottinghaus, P. J., Buelow, K. L., Matyja, A. ve Schneider, M. R. (2012). The career futures inventory-revised: Measu-ring dimensions of career adaptability. Journal of Career Assessment, 20(2), 123-129. doi:10.1177/1069072711420849

Sarıkaya, T. ve Khorshid, L. (2009). Üniversite öğrencilerinin meslek seçimini etkileyen etmenlerin incelenmesi, Türk Eğitim Bilimleri Dergisi, 7(2), 393-423.

Savickas, M. L. (1997). Career adaptability: Integrative construct for life- span, life- space theory. The Career Development Quarterly, 45, 247259.

Savickas, M. L. (1999). The transition from school- to- work: A developmental perspective. The Career Development Quarterly, 47, $326-336$.

Savickas, M. L. (2005). The theory and practice career construction. R. W. Lent ve S. D. Brown (Ed). Career development and counseling; putting theory and research to work (pp. 42-71). New Jersey: John Wiley \& Inc.

Scheier, M. E. ve Carver, C. S. (1987). Dispositional optimism and physical well-being: The influence of generalized outcome expectancies on health. Journal of Personality, 55 (2), 170- 210.

Scheier, M. F., Carver C. S. ve Bridges, M. W. (1994). Distinguishing optimism from neuroticism (and trait anxiety, self-mastery and self- esteem): A reevaluation of the life orientation test. Journal of Personality and Social Psychology, 67(6), 1063-1078.

Scholessberg, N. K., Waters, E.B. ve Goodman, J. (1995). Counseling adults in transition: Linking practice with theory (5th Ed) (Elektronik Sürüm). New York: Springer Publishing Company.

Schulenberg, J. E., Bryant, A. L. ve O'malley, P. M. (2004). Taking hold of some kind of life: How developmental tasks relate to trajectories of wellbeing during the transition to adulthood. Development and Psychopathology, 16, 1119-1140.

Seligman, L. (1994). Developmental career counseling and assessment. Thousand Oaks, CA: Sage Publications.

Super, D.E. (1983). Assessment in career guidance: Toward truly developmental counseling. Personnel and Guidance Journal, 61, 555-562.

Super, D. E. (1980). A life-span, life-space approach to career development. Journal of Vocational Behavior, 16, $282-298$.

Super, D. E. ve Hall, T. D. (1978). Career development: Exploration and planning. Annual Reviews Psychology, $29,333-372$.

Tolentino, L.R., Garcia, P.R.J.M., Lu, V.N, Restubog, S.L.D., Bordia, P. ve Plewa, C. (2014). Career adaption: The rela-tion of adaptability to goal orientation, proactive personality, and career optimism. Journal of Vocational Behavior, 84(1):39-48. doi: 10.1016/j.jvb.2013.11.004

Tolentino, L.R., Garcia, P.R.J.M., Lu, V.N., Restubog, S.L.D., Bordia, P. ve Tang, R.L. (2013). Validation of the Career Adapt-Abilities Scale and an examination of a model of career adaptation in the Philippine context. Journal of Vocational Behavior, 83, 410-418. http://dx.doi.org/10.1016/j.jvb.2013.06.013

Türk İstatistik Kurumu (2009). Gençlerin işgücü piyasasına geçişi araştırma sonuçları, http://www.tuik.gov.tr/PreHaberBultenleri.do?id=8373

Türk İstatistik Kurumu (2014). Hanehalkı İşücü İstatistikleri, Eylül 2014 http://www.tuik.gov.tr/PreHaberBultenleri.do?id=16014

Türk İstatistik Kurumu (2016a). İşgücü İstatistikleri, Nisan 2016. http://www.tuik.gov.tr/PreHaberBultenleri.do?id=21572

Türk İstatistik Kurumu (2016b). İ̧̧ücü istatistikleri, 2014 ve sonrası https://biruni.tuik.gov.tr/medas/?kn=72\&locale=tr

Üstün, G., Dedekoç, Ş., Kavalalı, T., Öztürk, F., Sapcı ,Y. ve Can, S. (2014). Üniversite son sınıf öğrencilerinin iş bulmaya ilişkin umutsuzluk düzeylerinin incelenmesi. Amasya Üniversitesi Eğitim Fakültesi Dergisi, 3(2), 200-221.

XLSATAT (2015). When to use the Welch and the Brown-Forsythe ANOVA https://www.xlstat.com/en/solutions/features/welch-and-brownforsythe-one-way-anova

Yazar-Aslan, B. (2015). Genç işsizliğe yönelik alan araştırması: Üniversite öğrencileri arasında kaygı ve umutsuzluk. Çalışma ilişkileri Dergisi 6(2), 71-86. 